\title{
Potential of pharmacological and herbal for COVID-19: a narrative review
}

\author{
Syahrul Tuba $\mathbb{D}^{*}$, Tesia Aisyah Rahmania (i) \\ Faculty of Military Pharmacy, The Republic of Indonesia Defense University, Jl. Sentul - Citeureup, Sentul, Citeureup, Bogor, \\ West Java 16810, Indonesia \\ *Corresponding author: Jl. Sentul - Citeureup, Sentul, Citeureup, Bogor, West Java 16810. Email: syahrulpharm@gmail.com
}

\begin{abstract}
The pandemic coronavirus disease 2019 (COVID-19) caused by severe acute respiratory syndrome coronavirus 2 (SARSCoV-2) presents an unprecedented challenge to identify effective drugs in the prevention and treatment process. At present, there is no proven therapy for this disease, although therapeutic approaches continue to be carried out using traditional medicines (herbal) and pharmacological therapy. Information about SARS-CoV-2 virology has rapidly developing and scientists try to provide a number of potential drugs. Remdesivir has strong in vitro activity against SARS-CoV-2. Several potential drugs are currently underway in a clinical trial. Chloroquine, hydroxychloroquine, and oseltamivir have not been proven to have efficacy, and the benefits of corticosteroids are still diverse. Current clinical evidence does not support the termination of angiotensin converting enzyme 2 (ACE2) inhibitors or angiotensin receptor blockers, coagulation therapy in patients with COVID-19 concomitant with comorbidities.
\end{abstract}

Keywords: COVID-19, herbal, pharmacology, therapy

\section{Introduction}

Coronavirus is one of a large family of viruses that can be found in humans as well as animals. The first report of a SARS-CoV-2 virus infection patient that was able to attract world attention occurred at the end of December 2019 in Wuhan, China. On February 11, 2020, the International Taxonomy Institute named this virus "Severe Acute Respiratory Syndrome Coronavirus type 2 (SARS-CoV-2)" as the official name for this type of virus, previously known as 2019-nCoV [1].

SARS-CoV type 2 is belonged to virus family that caused SARS and MERS. SARS-CoV-2 binds to the ACE2 receptor on lung cells through the receptor binding domain, then enters the cell and multiply, causing clinical symptoms found in infectious patients such as fever, cough, flu, and loss smell. The SARSCoV-2 virus is mostly transmitted by coughing or sneezing during close physical contact. Asymptomatic, pre-symptomatic, and symptomatic carriers can transfer infection [2].

\section{Pathophysiology}

Coronavirus is found in humans and other mammals as a single-stranded RNA virus in dogs, cats, chickens, cows, pigs, and birds. Coronavirus causes disorders of the lungs, gastrointestinal tract, and nervous system. SARS-CoV type 2 is a thirdgeneration coronavirus that has spread extensively in the last two decades, causing severe sickness in people [3]. SARS-CoV pandemic, began in China in 20022003 and was the first coronavirus to cause serious illness [4], while MERS was first reported in the Arabian Peninsula in 2012 [5]. The coronavirus may adapt and infect new hosts through recombination processes and genetic variety. In addition to the bat, new research reveals that humans get infected through a pangolin intermediate host $[7,8]$.

\section{Pathogenesis}

At the beginning of infection, the SARS-CoV-2 targets several human cells through viral $S$ protein that binds to the ACE2 [9], whereas protease 2 transmembrane serine protease (TMPRSS2) promotes viral absorption by cleaving ACE2. ACE2 and TMPRSS2 are expressed especially in type II alveolar epithelial cells in the respiratory tract $[10,11]$.

Severe lymphopenia can develop in COVID-19 patients when the SARS-CoV-2 attacks and destroys $\mathrm{T}$ cells. Furthermore, an inflammatory viral response that includes may harm lymphopoiesis while also increasing lymphocyte apoptosis. It has been suggested that ACE2 receptor upregulation from ACE inhibitors 
and angiotensin receptor blocking drugs increases susceptibility to SARS-CoV-2 infection; however, a large cohort research comprising 4480 COVID-19 patients in Denmark discovered no link between the two drug classes and the risk of infection or mortality in the hospital $[12,13]$.

In severe COVID-19 patients, the incidence of severity of coagulation activation and blood clotting factors was found. This is evidenced by a study in China, showing that $71 \%$ of the 183 people who died due to COVID-19 were found to have intravascular coagulation diffusion, a condition of impaired blood flow characterized by excessive blood clotting, causing blockage (thrombus) in the blood vessels in various organs in the human body [14].

\section{Transmission}

Droplets released when speaking face-to-face, coughing, or sneezing are the most prevalent mechanisms of transmission, according to epidemiological statistics. Transmission is more likely when spend more time with an infected individual (within 1-2 meters for at least 15 minutes) and spend less time with symptomatic persons, but brief exposure to asymptomatic contact has a lower risk [16]. Another mode of transmission is through surface contact by touching a virus-infected object's surface. However, the significance of this transmission is difficult to assess.

Viruses can also be detected 3 to 4 days after inoculation on impermeable surfaces [17]. Virus contamination is also found in several hospital treatment rooms; however, it is estimated that the number of viruses detected on the surface of these objects decreases rapidly within 48 to 72 hours due to routine disinfection [18]. The presence of the virus on the surface of objects strengthens the potential for virus transmission through door handles, eating utensils, and droplets through close direct face-toface contact is still the main factor in the process of spreading the virus.

\section{Symptoms and Signs}

Common symptoms that occur in COVID-19 patients are cough, fever, shortness of breath, myalgia, and fatigue $[19,20]$. Changes in the sense of smell or taste appear to be common finding in patients with mild/moderate disease; these symptoms sometimes appear before other COVID-19 symptoms [21]. As for the presentation of the severity of COVID-19 patients, around $80 \%$ were with mild disease, $14 \%$ with severe disease, and 5\% with critical illness.

Some COVID-19 patients will show no symptoms, although the exact proportions are not clear. Limited evidence from several countries suggests that up to $12 \%$ of SARS-CoV-2 transmission can occur through asymptomatic individuals [22]. It is likely to be higher in some places such as nursing homes [23]. Auscultation of the chest may reveal inflammation of the airways, rales (crepitus), and/or bronchial breathing in a patient with pneumonia or respiratory distress. Auscultation should be reserved for those who are important for decision making. Patients with respiratory distress may experience tachycardia, tachypnea, or cyanosis that accompanies hypoxia (23).

Doctors assessing COVID-19 patients should be aware of a phenomenon called "silent hypoxia", which is a lowered drop in oxygen saturation and triggers acute respiratory failure without any obvious respiratory symptoms. Only a minority of patients have other organ dysfunction, which means that after the initial phase of acute damage, traditional methods of recognizing further damage (e.g. NEWS2 score) cannot help predict patients with respiratory failure [24]. Although most patients with COVID-19 in the community will have mild disease, caution is needed when having respiratory symptoms and signs in patients with suspected COVID-19.

\section{Supportive Therapy}

Currently, the available therapeutic strategy for treating SARS-COV-2 infection is supportive and transmission prevention. There are four possible strategies to be applied: (i) consume of nutritious foods to boost immunity; (ii) use of masks and face shields; (iii) use of essential oils as air disinfectants to stop aerosol transmission; and (iv) use disinfectant [25].

Many plant and substances are known to have antiviral and immunomodulatory properties such as Aloe vera, astragalus, ganoderma, ginseng, curcumin, cinnamaldehyde, allicin, and piperin [26]. This activity is based on selective stimulation of cytokines, activation of lymphocytes, increasing the number of natural killer cells and increasing the activity of macrophages. Several natural products, such as baicalein and baicalin, have also been proven to suppress SARS-CoV-2 [27]. The herbal remedy Lian Hua Qing wen may suppress SARS-CoV-2 replication and reduce pro-inflammatory cytokine (Table 1) [28]. 
Table 1. Herbals that have the potential as antivirus for corona

\begin{tabular}{|c|c|c|c|c|}
\hline Herbals & Compound/extract & Testing Model & Mechanism of action & References \\
\hline \multirow[t]{14}{*}{ Lianhuaqingwen } & $\begin{array}{l}\text { Forsythia suspensa (Thunb.) Vahl } \\
\text { (Weeping forsythia }\end{array}$ & \multirow{14}{*}{$\begin{array}{l}\text { Vero E6 model } \\
\text { with SARS-COV-2 } \\
\text { infection }\end{array}$} & \multirow{14}{*}{$\begin{array}{l}\text { Inactivation of } \\
\text { SARS-CoV-2 } \\
\text { replication, reduces } \\
\text { production of } \\
\text { pro-inflammatory } \\
\text { cytokines and affects } \\
\text { the morphology of } \\
\text { virus cell particles. }\end{array}$} & \multirow[t]{14}{*}[28,30]{} \\
\hline & $\begin{array}{l}\text { Ephedra sinica Stapf (Chinese } \\
\text { ephedra; }\end{array}$ & & & \\
\hline & $\begin{array}{l}\text { Lonicera japonica Thunb. } \\
\text { (Japanese honeysuckle; }\end{array}$ & & & \\
\hline & Isatis indigotica Fortune & & & \\
\hline & Mentha haplocalyx Briq. & & & \\
\hline & $\begin{array}{l}\text { Dryopteris crassirhizoma Nakai } \\
\text { (Thickstemmed wood fern) }\end{array}$ & & & \\
\hline & Rhodiola rosea L. (Golden root) & & & \\
\hline & Gypsum Fibrosum (Gypsum) & & & \\
\hline & Pogostemon cablin (Blanco) Benth. & & & \\
\hline & (Patchouli) & & & \\
\hline & $\begin{array}{l}\text { Rheum palmatum L. (Chinese } \\
\text { rhubarb) }\end{array}$ & & & \\
\hline & $\begin{array}{l}\text { Houttuynia cordata Thunb. (Fish } \\
\text { mint) }\end{array}$ & & & \\
\hline & $\begin{array}{l}\text { Glycyrrhiza uralensis Fisch. } \\
\text { (Liquorice) }\end{array}$ & & & \\
\hline & $\begin{array}{l}\text { Armeniaca sibirica (L.) Lam. } \\
\text { (Siberian apricot) }\end{array}$ & & & \\
\hline $\begin{array}{l}\text { Rhizoma cibotii } \\
\text { (Rhizome of } \\
\text { Scythian Lamb) }\end{array}$ & Extract Rhizoma cibotii & $\begin{array}{l}\text { Vero cell model } \\
\text { with SARS-CoV-1 } \\
\text { infection }\end{array}$ & $\begin{array}{l}\text { Inhibits the } \\
\text { replication of the } \\
\text { SARS-CoV-1 virus }\end{array}$ & \\
\hline
\end{tabular}

It is also suggested that inhaling essential oil vapor increases the suppression of airborne germs and viruses. Citrus bergamia, Eucalyptus globulus, Pelargonium graveolens, Cinnamomum zeylanicum leaf oil, and Cymbopogon flexuosus are some of the essential oil vapors that have been shown to have anti-influenza viral activity. [29]. Using essential oils to disinfect the air without risking human health could be an efficient way to halt the spread of COVID-19. However, the minimum essential oil concentration required to reduce SARS-CoV-2 should be investigated further. To enhance the immune system and defend the body from COVID-19, a combination of immunomodulatory foods and herbs is recommended. Other scientific investigations or clinical trials must, however, validate these findings.

\section{Potential candidates for pharmacological therapy of COVID-19}

At this time, there is no known anti-viral drug that has been proven to work for COVID-19. Several clinical trials are undergoing such as remdesivir, favipiravir, plasma convalescent, hyper-immune immunoglobulin, dexamethasone, statins, tocilizumab, sarilumab, anakinra, ruxolitinib, heparin, and antifibrotics. At various phases of the disease and in different manifestations of the disease, the use of those medications is likely to have varied qualities. Viral suppression is likely to be most effective at the outset of infection, whereas immunomodulatory drugs and anticoagulants can help reduce disease development and thromboembolic consequences in hospitalized patients [18].

The majority of antiviral medications presently being tested on COVID-19 patients were initially created to combat the influenza virus, HIV, Ebola, or SARS/ MERS [31]. When compared to standard therapy, the protease inhibitor lopinavir-ritonavir had no effect in 199 hospitalized adult patients with severe COVID-19 [32]. Meanwhile, the use of ribavirin, favipiravir, and remdesivir, which block viral replication, these drugs seem to show the most promising results [31,33]. 
Patients who were given remdesivir had a faster recovery time than those who were given a placebo (11 vs 15 days) [33].

During the 1918 flu pandemic, plasma therapy from individuals who had recovered from viral illness was first recorded. The first reports of five severely sick COVID-19 patients who were administered convalescent plasma shown improved clinically outcome [34]. In a clinical trial involving 103 Chinese patients with severe COVID-19, no significant differences in clinical improvement were found between those assigned to conventional plasma vs standard therapy at 28 days $(51.9 \%$ vs. $43.1 \%)$. Alternatively, blood plasma-derived hyper-immune globulin and monoclonal antibodies targeting the SARS-CoV-2 virus are presently being studied [35].

Another promising therapy strategy is monoclonal antibodies that target inflammatory mediators such as IFN- $\gamma$, IL-1, IL-6 to avoid organ damage in COVID-19 patients [36]. Tocilizumab and sarilumab, an IL-6 inhibitor, are a good option for COVID-19 patients. Tyrosine kinase inhibitors (such as imatinib) are still being researched for their ability to reduce pulmonary blood vessel leakage in COVID-19 patients.

In trials, corticosteroids have had inconsistent results when used to treat viral pneumonia and acute respiratory distress syndrome (ARDS). In the RECOVERY Trial, 2104 individuals with COVID-19 who received $6 \mathrm{mg}$ of dexamethasone daily for 10 days versus 4321 patients who received standard therapy were proven to survive longer [37]. according to a retrospective cohort investigation, methylprednisolone therapy reduced the risk of mortality in 201 patients with COVID-19 pneumonia and ARDS in Wuhan, China [38]. The use of corticosteroids in individuals with a shorter duration of symptoms and who do not require supplementary oxygen, on the other hand, has shown to be ineffective [18].

Subcutaneous low molecular weight heparin for thromboembolic prevention should be given to almost all COVID-19 patients who are hospitalized. Currently, there are over 300 clinical therapeutic trials in progress. There is presently no solid evidence that any medicine can improve outcomes based on randomized clinical studies (Table 2).

\section{Conclusion}

COVID-19 patients commonly experience fever, dry cough, and shortness of breath. Lymphopenia and increased lactate dehydrogenase are two frequent radiographic and laboratory findings. Sepsis and rapid respiratory failure can define COVID-19 symptoms, including asymptomatic carriers and fulminant/ severe illness. Around 20\% of COVID-19 hospitalized patients have severe symptoms that intensive care, and more than $75 \%$ of COVID-19 hospitalized patients require supplementary oxygen treatment. In people who need supplemental oxygen, dexamethasone medication reduces 28 -day mortality, while the use of remdesivir reduces the time it takes to recover from 15 to 11 days (release from hospital or no need for extra oxygen). The use of convalescent plasma did not decrease recovery time in a randomized study of 103 individuals with COVID-19. Antiviral treatment, immune modulators, and anticoagulants are now being tested. In the United States, the case-fatality rate varies substantially with age, ranging from 0.3 deaths per 1000 cases in patients aged 5 to 17 years to 304.9 deaths per 1,000 cases in patients 85 years and older. Case fatality of patients hospitalized to the

Table 2. Several potential drugs that are still in the clinical trial for COVID 19

\begin{tabular}{ll}
\hline Drug & Use \\
\hline Remdesivir & Patient MERS CoV and Ebola \\
Lopinavir/ritonavir & $50 \%$ decreased MERS CoV activity \\
Ribavirin & Patients with MERS CoV infection \\
Oseltamivir/Tamiflu & Patients with influenza \\
Chloroquine/hydroxychloroquine + Azithromycin & Malaria, lupus, arthritis \\
Convalescent plasma therapy & Patients with influenza \\
ChAdOx1 nCoV-19 vaccine & COVID-19 clinical trials \\
Vitamin C & CITRIS-ALI trial \\
\hline
\end{tabular}


intensive care unit (ICU) can reach 40\%. At least 120 vaccines against SARS-CoV-2 are in the works. Face masks, social distancing, and contact tracking are the key strategies of controlling transmission until a viable vaccine is available. Monoclonal antibodies and hyperimmune globulin are two other techniques that can be employed to stop the virus from spreading.

\section{Acknowledgment}

None.

\section{Declaration of interest}

The authors declare no conflict of interests in the journal publication of this article.

\section{Author contribution}

ST constructed the study design. ST and TAR performed and analyzed the article. TAR prepared the first draft manuscript and ST revised the final version of the paper. ST and TAR have read the final manuscript.

Received: 26 December 2020

Accepted: 14 February 2021

Published online: 31 August 2021

\section{References}

1. Lai C-C, Shih T-P, Ko W-C, Tang H-J, Hsueh P-R. Severe acute respiratory syndrome coronavirus 2 (SARS-CoV-2) and coronavirus disease-2019 (COVID-19): The epidemic and the challenges. Int J Antimicrob Agents. 2020;55: 105924. doi:10.1016/j.ijantimicag.2020.105924

2. Wu P, Liu F, Chang Z, Lin Y, Ren $M$, Zheng C, et al. Assessing asymptomatic, pre-symptomatic and symptomatic transmission risk of SARS-CoV-2. Clin Infect Dis. 2021; doi:10.1093/cid/ciab271

3. Zhu N, Zhang D, Wang W, Li X, Yang B, Song J, et al. A Novel Coronavirus from Patients with Pneumonia in China, 2019. N Engl J Med. 2020;382: 727-733. doi:10.1056/NEJMoa2001017

4. Zhong NS, Zheng BJ, Li YM, Poon, Xie ZH, Chan KH, et al. Epidemiology and cause of severe acute respiratory syndrome (SARS) in Guangdong, People's Republic of China, in February, 2003. Lancet. 2003;362: 1353-1358. doi:10.1016/s0140-6736(03)14630-2

5. Zaki AM, van Boheemen S, Bestebroer TM, Osterhaus ADME, Fouchier RAM. Isolation of a novel coronavirus from a man with pneumonia in Saudi Arabia. N Engl J Med. 2012;367: 1814-1820. doi:10.1056/NEJMoa1211721

6. Goldsmith CS, Tatti KM, Ksiazek TG, Rollin PE, Comer
JA, Lee WW, et al. Ultrastructural characterization of SARS coronavirus. Emerging Infect Dis. 2004;10: 320326. doi:10.3201/eid1002.030913

7. Lu R, Zhao X, Li J, Niu P, Yang B, Wu H, et al. Genomic characterisation and epidemiology of 2019 novel coronavirus: implications for virus origins and receptor binding. Lancet. 2020;395: 565-574. doi:10.1016/S01406736(20)30251-8

8. Lam TT-Y, Jia N, Zhang Y-W, Shum MH-H, Jiang J-F, Zhu $\mathrm{H}-\mathrm{C}$, et al. Identifying SARS-CoV-2-related coronaviruses in Malayan pangolins. Nature. 2020;583: 282-285. doi:10.1038/s41586-020-2169-0

9. Hoffmann M, Kleine-Weber H, Schroeder S, Krüger N, Herrler T, Erichsen S, et al. SARS-CoV-2 Cell Entry Depends on ACE2 and TMPRSS2 and Is Blocked by a Clinically Proven Protease Inhibitor. Cell. 2020;181: 271280.e8. doi:10.1016/j.cell.2020.02.052

10. Sungnak W, Huang N, Bécavin C, Berg M, Queen R, Litvinukova $\mathrm{M}$, et al. SARS-CoV-2 entry factors are highly expressed in nasal epithelial cells together with innate immune genes. Nat Med. 2020;26: 681-687. doi:10.1038/ s41591-020-0868-6

11. Zou X, Chen K, Zou J, Han P, Hao J, Han Z. Single-cell RNA-seq data analysis on the receptor ACE2 expression reveals the potential risk of different human organs vulnerable to 2019-nCoV infection. Front Med. 2020;14: 185-192. doi:10.1007/s11684-020-0754-0

12. Fosbøl EL, Butt JH, Østergaard L, Andersson C, Selmer C, Kragholm K, et al. Association of Angiotensin-Converting Enzyme Inhibitor or Angiotensin Receptor Blocker Use With COVID-19 Diagnosis and Mortality. JAMA. 2020;324: 168-177. doi:10.1001/jama.2020.11301

13. Mancia G, Rea F, Ludergnani M, Apolone G, Corrao G. Renin-Angiotensin-Aldosterone System Blockers and the Risk of Covid-19. N Engl J Med. 2020;382: 2431-2440. doi:10.1056/NEJMoa2006923

14. Tang N, Li D, Wang X, Sun Z. Abnormal coagulation parameters are associated with poor prognosis in patients with novel coronavirus pneumonia. J Thromb Haemost. 2020;18: 844-847. doi:10.1111/jth.14768

15. Klok FA, Kruip MJHA, van der Meer NJM, Arbous MS, Gommers DAMPJ, Kant KM, et al. Incidence of thrombotic complications in critically ill ICU patients with COVID-19. Thromb Res. 2020;191: 145-147. doi:10.1016/j.thromres.2020.04.013

16. Chu DK, Akl EA, Duda S, Solo K, Yaacoub S, Schünemann $\mathrm{HJ}$, et al. Physical distancing, face masks, and eye protection to prevent person-to-person transmission of SARS-CoV-2 and COVID-19: a systematic review and meta-analysis. Lancet. 2020;395: 1973-1987. doi:10.1016/ S0140-6736(20)31142-9

17. van Doremalen N, Bushmaker T, Morris DH, Holbrook MG, Gamble A, Williamson BN, et al. Aerosol and Surface Stability of SARS-CoV-2 as Compared with SARSCoV-1. N Engl J Med. 2020;382: 1564-1567. doi:10.1056/ NEJMc2004973 
18. Wiersinga WJ, Rhodes A, Cheng AC, Peacock SJ, Prescott HC. Pathophysiology, Transmission, Diagnosis, and Treatment of Coronavirus Disease 2019 (COVID-19): A Review. JAMA. 2020;324: 782-793. doi:10.1001/ jama.2020.12839

19. Docherty AB, Harrison EM, Green CA, Hardwick HE, Pius R, Norman L, et al. Features of 20133 UK patients in hospital with covid-19 using the ISARIC WHO Clinical Characterisation Protocol: prospective observational cohort study. BMJ. 2020;369: m1985. doi:10.1136/bmj. m1985

20. Li L-Q, Huang T, Wang Y-Q, Wang Z-P, Liang Y, Huang T-B, et al. COVID-19 patients' clinical characteristics, discharge rate, and fatality rate of meta-analysis. J Med Virol. 2020;92: 577-583. doi:10.1002/jmv.25757

21. Lechien JR, Chiesa-Estomba CM, De Siati DR, Horoi M, Le Bon SD, Rodriguez A, et al. Olfactory and gustatory dysfunctions as a clinical presentation of mild-tomoderate forms of the coronavirus disease (COVID-19): a multicenter European study. Eur Arch Otorhinolaryngol. 2020;277: 2251-2261. doi:10.1007/s00405-020-05965-1

22. Vetter P, Vu DL, L'Huillier AG, Schibler M, Kaiser L, Jacquerioz F. Clinical features of covid-19. BMJ. 2020;369: m1470. doi:10.1136/bmj.m1470

23. Gandhi M, Yokoe DS, Havlir DV. Asymptomatic Transmission, the Achilles' Heel of Current Strategies to Control Covid-19. N Engl J Med. 2020;382: 2158-2160. doi:10.1056/NEJMe2009758

24. Huang C, Wang Y, Li X, Ren L, Zhao J, Hu Y, et al. Clinical features of patients infected with 2019 novel coronavirus in Wuhan, China. Lancet. 2020;395: 497-506. doi:10.1016/ S0140-6736(20)30183-5

25. Panyod S, Ho C-T, Sheen L-Y. Dietary therapy and herbal medicine for COVID-19 prevention: A review and perspective. J Tradit Complement Med. 2020;10: 420-427. doi:10.1016/j.jtcme.2020.05.004

26. Tan BKH, Vanitha J. Immunomodulatory and antimicrobial effects of some traditional chinese medicinal herbs: a review. Curr Med Chem. 2004;11: 1423-1430.

27. Su H, Yao S, Zhao W, Li M, Liu J, Shang W, et al. Discovery of baicalin and baicalein as novel, natural product inhibitors of SARS-CoV-2 3CL protease in vitro. BioRxiv. 2020; doi:10.1101/2020.04.13.038687

28. Runfeng L, Yunlong H, Jicheng H, Weiqi P, Qinhai M, Yongxia S, et al. Lianhuaqingwen exerts anti-viral and antiinflammatory activity against novel coronavirus (SARS-
CoV-2). Pharmacol Res. 2020;156: 104761. doi:10.1016/j. phrs.2020.104761

29. Choi H-J. Chemical Constituents of Essential Oils Possessing Anti-Influenza A/WS/33 Virus Activity. Osong Public Health Res Perspect. 2018;9: 348-353. doi:10.24171/j.phrp.2018.9.6.09

30. Liang C, Hui N, Liu Y, Qiao G, Li J, Tian L, et al. Insights into forsythia honeysuckle (Lianhuaqingwen) capsules: A Chinese herbal medicine repurposed for COVID-19 pandemic. Phytomedicine Plus. 2021;1: 100027. doi:10.1016/j.phyplu.2021.100027

31. Scavone C, Brusco S, Bertini M, Sportiello L, Rafaniello C, Zoccoli A, et al. Current pharmacological treatments for COVID-19: What's next? Br J Pharmacol. 2020;177: 4813-4824. doi:10.1111/bph.15072

32. Cao B, Wang Y, Wen D, Liu W, Wang J, Fan G, et al. A Trial of Lopinavir-Ritonavir in Adults Hospitalized with Severe Covid-19. N Engl J Med. 2020;382: 1787-1799. doi:10.1056/NEJMoa2001282

33. Beigel JH, Tomashek KM, Dodd LE, Mehta AK, Zingman BS, Kalil AC, et al. Remdesivir for the Treatment of Covid-19 - Final Report. N Engl J Med. 2020;383: 18131826. doi:10.1056/NEJMoa2007764

34. Shen C, Wang Z, Zhao F, Yang Y, Li J, Yuan J, et al. Treatment of 5 Critically Ill Patients With COVID-19 With Convalescent Plasma. JAMA. 2020;323: 1582-1589. doi:10.1001/jama.2020.4783

35. Wang C, Li W, Drabek D, Okba NMA, van Haperen R, Osterhaus ADME, et al. A human monoclonal antibody blocking SARS-CoV-2 infection. Nat Commun. 2020;11: 2251. doi:10.1038/s41467-020-16256-y

36. Alzghari SK, Acuña VS. Supportive Treatment with Tocilizumab for COVID-19: A Systematic Review. J Clin Virol. 2020;127: 104380. doi:10.1016/j.jcv.2020.104380

37. RECOVERY Collaborative Group, Horby P, Lim WS, Emberson JR, Mafham M, Bell JL, et al. Dexamethasone in Hospitalized Patients with Covid-19. N Engl J Med. 2021;384: 693-704. doi:10.1056/NEJMoa2021436

38. Wu X, Cai Y, Huang X, Yu X, Zhao L, Wang F, et al. Co-infection with SARS-CoV-2 and Influenza A Virus in Patient with Pneumonia, China. Emerging Infect Dis. 2020;26: 1324-1326. doi:10.3201/eid2606.200299

39. Levi M, Thachil J, Iba T, Levy JH. Coagulation abnormalities and thrombosis in patients with COVID-19. Lancet Haematol. 2020;7: e438-e440. doi:10.1016/S23523026(20)30145-9 